ON SOME FOSSIL PEARL-GROWTHS.

By J. Wilfrid JAcrson, F.G.S. (Manchester Museum).

Read 16th April, 1909.

PLATE XIV.

AfTER reading Mr. R. Bullen Newton's highly interesting article on "Fossil Pearl-growths" (antea, pp. 128-39), I at once commenced to hunt up specimens of fossil pearls in the collections at the Manchester Museum, and am pleased to be able to add other examples to Mr. Newton's list. An account of these may not be without interest to readers, and may stimulate further search for these objects. The following are the examples which have, so far, come under my notice. For the sake of uniformity Mr. Newton's excellent method of description is adopted.

\title{
Family MYTILID在.
}

Mrtilus edulis, Linnæus. Pl. XIV, Figs. A, B.

In the late Mr. R. D. Darbishire's large series of shells from the Raised Beach of Uddevalla, there is quite a number of odd valves of the above species, each containing one or more examples of attached pearls. Some of the valves contain many of these bodies, as will be seen by the larger example figured on Pl. XIV, Fig. A. Several small isolated pearls, of irregular shapes and varying in size, are also included in the same collection.

Geological age.-Post-Pliocene (Raised Beach).

Locality.-Uddevalla, Sweden.

Collection.-Manchester Museum (R. D. Darbishire Coll.)[L.3120].

\section{Family AVICULID无.}

Inoceramus (?). Pl. XIV, Fig. C.

Amongst a large collection of Cambridge Greensand fossils presented by the Rev. A. Dixon in 1901, I recently came across a rather fine example of a pearl. Its greatest diameter is $9 \mathrm{~mm}$., and various growth layers can be seen in places where the outer crust has been fractured. The colour of the pearl is a dirty steel-grey. Like the Crag examples, no doubt this specimen was of derivative origin.

Geological age. - Cretaceous (Albian). Found in the so-called Cambridge Greensand.

Locality.-Cambridge.

Collection.-Manchester Museum (Rev. A. Dixon Coll.) [L. 8702].

Inoceranus. Pl. XIV, Fig. D.

The Manchester Museum possesses three examples of pearls from the Crag deposits of Suffolk, presented by Mr. R. Cairns. In general characters they agree with the British Museum specimens referred to in Mr. Newton's paper (see pp. 136, 137). One, however, is still attached to a small portion of the shell. 
Geological age. - Cretaceous (Senonian). Found in the Crag deposits as probably derivative fossils from the Chalk.

Locality.-Near Orford Castle, Suffolk.

Collection.-Manchester Museum (R. Cairns Coll.) [L. 1550].

\section{Family OSTREID无.}

Ostrea edulis, Linnæus. Pl. XIV, Fig. E.

Attached to a valve of this species amongst a collection of Coralline Crag fossils in the Manchester Museum is an almost spherical pearl (see above plate). Like the shell itself, the pearl, which is about $4 \mathrm{~mm}$. in diameter, has lost a good deal of its beautiful nacreous nature, and appears almost porcellanous. Beyond the fact that it was originally in the old Manchester Museum and came from Ramsholt, no particular history is attached to it.

Geological age.-Pliocene (Coralline Crag).

Locality.-Ramsholt, Suffolk.

Collection.-Manchester Museum [L. 4696].

Ostrea tenera, J. Sowerby.

Ostrea tenera, J. Sowerby: Min. Conch., 1819, vol. iii, p. 95, pl. eclii, figs. 2, 3.

Whilst cleaning up and working out the material from between the valves of a specimen of the above species in the Caroline Birley Collection, I came across a small spherical body, not quite $2 \mathrm{~mm}$. in diameter, bearing a strong resemblance to a pearl. It is dirty brown in colour, but exhibits the characteristic nacreous lustre.

Geological age._Lower Eocene (Woolwich Beds).

Locality._-Croydon Gasworks.

Collection.-Manchester Museum (Caroline Birley Coll.) [L. 8703].

Gryphea dilatata, J. Sowerby.

Gryphaa dilatata, J. Sowerby: Min. Conch., 1816, vol. ii, p. 113, pl. exlix.

Attached to the upper valve of a specimen of the above species are three small pearl-growths, close together, and situated very near the hinge. They are dark-coloured, and partake of the same nature as the shell itself.

Geological age.-Jurassic (Oxford Clay).

Locality.-Cowley, Oxford.

Collection._Manchester Museum (Manning Coll.) [L. 6360].

\section{Family LIMID A.}

Lima scabra, Born.

Lima scabra, Born: Index Mus. Cæsar. Vindobon., 1778, p. 110.

Amongst a small collection of Tertiary fossils collected by Sir William Rawson in the Bahamas are two odd valves of this species, and in the interior of one of these are a number of attached pearlgrowths. The shell is thick and coarsely grown, slightly deformed, 
and shows traces of disease in the interior, especially in the region of the large adductor impression and along the pallial line. It is on these impressions that the pearls, which are small and somewhat lustreless, are situated.

Geological age.-Late Tertiary.

Locality.-Bahamas.

Collection. - Manchester Museum (Sir William Rawson Coll.) [L. 4700].

\section{EXPLANATION OF PLATE XIV.}

Mytilus edulis, Linnæus. Post-Pliocene (Raised Beach): Uddevalla, Sweden.

Fig. A. Valves showing attached pearls of various shapes and sizes.

, B. Series of free pearls from same species.

Inoceramus (?). Albian (found in the so-called Cambridge Greensand): Cambridge.

Fig. C. Isolated pearl exhibiting growth layers on fractured surface.

Inoceramus. Senonian (found in the Crag deposits) : near Orford Castle, Suffolk.

FIg. D. Three examples of pearls, one of which still retains a small portion of the original shell.

Ostrea edulis, Linnæus. Pliocene (Coralline Crag): Ramsholt, Suffolk.

FIG. E. Upper valve of above species containing attached pearl.

All the figures are natural size. 


\section{$2 \mathrm{BHL}$ Biodiversity Heritage Library}

Jackson, J Wilfrid. 1909. "ON SOME FOSSIL PEARL-GROWTHS." Proceedings of the Malacological Society of London 8, 318-320.

View This Item Online: https://www.biodiversitylibrary.org/item/100060

Permalink: https://www.biodiversitylibrary.org/partpdf/203005

\section{Holding Institution}

Field Museum of Natural History Library

\section{Sponsored by}

Smithsonian

\section{Copyright \& Reuse}

Copyright Status: Public domain. The BHL considers that this work is no longer under copyright protection.

This document was created from content at the Biodiversity Heritage Library, the world's largest open access digital library for biodiversity literature and archives. Visit BHL at https://www.biodiversitylibrary.org. 